\title{
ІСТОРИЧНИЙ ШЛЯХ ФРАНКО-БЕЛЬГІЙСЬКОГО КОМІКСУ
}

У статті досліджено виникнення та розвиток коміксу як жанру масової літератури. Виявлено, що комікс має безліч наукових інтерпретачій. Ми розглядаємо комікс як «особливий жанр художнього оповідання у вигляді просторової послідовності малюнків у поєднанні з доповнювальним та уточнюючим їх текстом» (Харітонов, 2005). З'ясовано, щуо сам термін «комікс» був уведений у науковий обіг на початку ХІХ ст., однак у різних країнах комікси набули власного терміна (мальована історія, фуметті, більдербоген, манги, стріп, тебеос, маньхуа, ляньхуанхуа, графічний роман). Також виявлено, щзо протоформами сучасного коміксу є наскельні малюнки й житійні ікони, церковні малюнки (зображення в печерах, античні фрески).

Особливу увагу приділено становленню франко-бельгійського коміксу. Представлено вичерпний огляд основних журналів, які друкували оповіді в малюнках, їхню тематику, провідних франко-бельгійських коміксмейкерів $і$ їхні твори. 3'ясовано, щуо основними персонажами франко-бельгійського коміксу є Тентен (молодий журналіст, який боровся зі злочиниями, диктаторами, прославляв дружбу і захищав місиеве населення) та Астерікс (галльський герой, ше веде відважну боротьбу з римськими загарбниками). До базових видів коміксу віднесено: синлл, ТРВ, гардковер, омнібус, графічний роман. Новими явищами в цььому виді мистецтва є блоги-комікси, веб-комікси, німі комікси. Визначено основні елементи верстки коміксу: панель, фрейм або бокс; поділ; сплеш, сплеш-сторінка; хмарка, балун, текстова хмаринка, бабл; вигуки, звуки або ономатопея. Встановлено, щзо основними жанрами коміксу є комедія, екшен, пригоди, антиутопія, автобіографія. Його тематика дуже різноманітна - від героїзму, шпіонажу, битви до реалістичної і дорослої: корупчія, вбивства, викрадення, вживання наркотиків, алкоголізм, забруднення навколишнього середовища, расизм тощзо.

На основі проведеного аналізу зроблено висновки, щуо франко-бельгійські комікси тяжіють до реалізму, авангарду, гумористики, орієнтуються на вимогливого та інтелектуально підкутого читача.

Ключові слова: масова література, комікс, BD, графічний роман, коміксмейкер, мовна булька.

Emiliia NIKOLAIESKU, orcid.org/0000-0002-1742-5991

Senior Lecturer at the Department of Eastern-European Languages of the Educational and Scientific Center for Language Training National Academy of the Security Service of Ukraine (Kyiv, Ukraine) emilie.nicolaescou@gmail.com

\section{THE HISTORICAL WAY OF THE FRANCO-BELGIAN COMICS}

The origin and development of comics as a genre of popular literature was explored in the article. It was found out that the comics had many scientific interpretations. The comics were regarded as "a special genre of fiction narration in the form of a spatial sequentiality of drawings in connection with a supplementary and refining text” (Kharitonov, 2005). There was substantiated that the term "comics" was introduced into sciences society in the early 19th century, but in different countries comics have acquired their own term (cartoon, fumetti, bilderbogen, strip, tebeos, mangas, manhua, lianhuanghua, graphic novel). It was also investigated that the protoforms of modern comics were rock paintings and life icons, church paintings (images in caves, antique frescoes).

There was made a special emphasis on the Franco-Belgian comic strip formation. There was represented a comprehensive overview of the major magazines that had published strip cartoons, their topics, and works of leading French-Belgian comic book makers. It was revealed that the main characters of the Franco-Belgian comic books were Tenten (a young journalist who fought criminals, dictators, glorified friendship and defended the local population) and Asterix (Gallic hero, waging a brave struggle against the Roman invaders). The basic types of comics include: single, $T P B$, hardcover, omnibus, graphic novel. There are some new phenomena in this kind of art as blog comics, web comics, silent comics. The basic elements of the comic strip layout had been identified, they were: panel, frame or box; division; splash, splash page; cloud, balloon, text cloud, bubble; exclamations, sounds or onomatopoeia. There was established that the main genres of comics were comedy, action, adventure, dystopia, autobiography. Comics were of diverse subject matter and their topics ranged from heroism, espionage, battle to the realistic and adult: corruption, murder, kidnapping, drug consumption, alcoholism, environmental pollution, racism and others. 
Based on the conducted analysis, there was made a conclusion that the Franco-Belgian comics showed a tendency to actuality, avant-garde, humoristics, and oriented to the demanding and intellectually versed reader.

Key words: popular literature, comics, BD, graphic novel, comic book maker, speech balloon.

Постановка проблеми. Останнім часом масова література стає вподобанням великої аудиторії та предметом вивчення багатьох наук, зокрема літературознавства, лінгвістики, семіотики, психології, практики перекладу. Незважаючи на чималу кількість лінгвістичних досліджень, присвячених масовій літературі, зокрема коміксу, його засадам, специфіці, науковий інтерес до зазначеного жанру літератури не згасає. Комікс залишається об'єктом пильної уваги дослідників, зважаючи на неоднозначність і навіть суперечливість трактувань самого визначення коміксу. Недостатня кількість доробок вивчення франко-бельгійського коміксу зумовлює актуальність цього дослідження.

Аналіз досліджень. Що ж таке комікс? Учені дають цьому терміну різні визначення, оперуючи понятійними категоріями, що притаманні досліджуваній ними галузі знань. Одне 3 них ми знаходимо у Словнику української мови: «комікси пригодницькі (переважно про вбивства, отруєння тощо), рясно ілюстровані книжечки, розраховані на низькі уподобання та смаки» (Білодід, Бурячок, 1973: 246). Існує, однак, чимало інших визначень цього явища.

«Комікс (від англ. comic-комедійний, комічний, смішний; рідше вживається термін англ. sequential art - «послідовне мистецтво», яке використовує прийом «далі буде») - послідовність малюнків, зазвичай 3 короткими текстами, які створюють певну зв'язну розповідь. Тексти, як правило, мають специфічну форму «мовної бульки» («мовної хмарки», «мовного димка», виноски; англ. speech balloon), яка передає мову чи думку (мисль) персонажу, заголовків і титрів» (wikipedia).

У своїй праці «Суть коміксу» (англ. Understanding comics) американський коміксмейкер С. МакКлауд зазначає, що «комікс - це суміжні малюнки та інші зображення у смисловій послідовності» (McCloud, 1993). Наведемо ще кілька прикладів: «графічна література - особливе мистецтво зі своїми законами будування та зображальними засобами», «оповідання в картинках, ілюстроване, за необхідністю, допоміжними текстами» (Барзах, 2010); «особливий жанр художнього оповідання у вигляді просторової послідовності малюнків у поєднанні $з$ доповнювальним та уточнюючим їх текстом» (Харітонов, 2005).

Отже, комікс - це порівняно молодий жанр масового мистецтва, який викликає до себе зацікавленість у всьому світі. Як зазначалося вище, комікс досліджували як вітчизняні, так і зарубіжні мовознавці, такі як А. Барзах, Д. Веклер, У. Еко, В. Срофеєв, С. Козлов, Н. Космацька, Ф. Лакасен, С. МакКлауд, Б. Пітер, О. Сонін, Е. Харітонов та ін.

Мета статті - дослідити процес розвитку франко-бельгійського коміксу, розглянути основні види коміксу та його структуру.

Виклад основного матеріалу. Зародження коміксу сягає глибокої давнини. Протоформами сучасного коміксу науковці вважають наскельні малюнки та житійні ікони, церковні малюнки, наприклад, зображення в печері Ласко у Франції, античні фрески в Єгипті, Римі, Греції. В Європі комікс з'явився у XV ст., однак сучасна форма коміксу (з панелями (панель у коміксі - окремий малюнок чи малюнок $з$ текстами), використанням тексту всередині картинки в «мовній бульці»), як і сам термін «комікс», датується першою половиною XIX століття.

У пресі малюнки вперше з'явилися у XVIII ст. завдяки англійському живописцю В. Хогарту, який $є$ одним із засновників серійності в коміксі. Автором першого коміксу «Histoire de M. Jabot» (написаний у 1831 р., виданий у 1833 р.) є швейцарський письменник Р. Топфер. Саме Р. Топфер започаткував коміксний альбом та поняття коміксного персонажа (Космацька, 2012: 142). Послідовниками Р. Топфера стали французький графік Шам та французький живописець Г. Доре, чия книжка-альбом «Мальовнича, драматична та карикатурна історія Святої Русі на підставі текстів хронікерів і істориків Нестора, Сильвестра, Карамзина, Сегура і т. д. в 500 рисунках з коментарями» (фр. Histoire pittoresque dramatique et caricaturale de la Sainte Russie, d'après les chroniqueurs et historiens Nestor Nikan Sylvestre Karamsin Ségur etc.) (1854) вважається одним із перших провісників мистецтва коміксу. До основоположників жанру коміксів належить і німецький поет-сатирик, художник Г. Буш (1832-1908). Його дотепні сатиричні вірші в картинках популярні в усьому світі (наприклад вірш «Пліх і Плюх»).

Першим виданням, присвяченим пригодам одного героя, став британський комікс «Ally Sloper's Half Holiday» Ч. Росса, що розповідав про пригоди лінивого та шахраюватого Александра Слопера і виходив $31884 \mathrm{p}$.

Хоча з'явилися комікси в Європі, найбільшого розвитку ця індустрія зазнала в США. Перший американський комікс «Ведмежата і тигр» 
вийшов у 1892 р. в журналі «The San Francisco Examiner». У другій половині XIX століття 3'явилися комікси 3 постійними героями, наприклад, «Жовтий малюк», що був створений Р. Аутколтом у 1895 p. і друкувався в газеті «New York World», а пізніше - $\mathrm{y}$ «New York Journal-American». Для американської культури комікс - живий жанр, який невпинно розвивається й щороку відкриває публіці нових авторів.

Щодо франко-бельгійської школи, BD (bande dessinée) - одна 3 найдавніших європейських традицій цього виду мистецтва, що має численних послідовників по всьому світу. За роки свого існування індустрія коміксів створила власну спеціалізовану термінологію. У різних країнах комікси набули власного терміну. Термін «комікс» характерний для США, багатьох англомовних країн, Польщі тощо. В Україні з 2000-х років ужився термін «мальовані історії» - загальний термін для позначення всіх видів мистецтва, послідовних зображень із сюжетом, розкадровками і текстами у хмарках-баблах, які є друкованими або цифровими творами. Також розрізняють: $B D$ (Франція, Бельгія), фуметті (Італія), більдербоген (Німеччина), стріп (Сербія, Хорватія), тебеос (Іспанія), манти (Японія), маньхуа (Гонконг), ляньхуанхуа (Китай), тощо. У 1960-х роках у Сполучених Штатах з'явився термін «графічний роман», щоб уникнути натяку на дитячість і розважальну конотацію «комічність» коміксів, особливо в тих країнах, де поширена назва «комікси».

Найстарішою французькою мальованою історією (BD) вважається передвиборча листівка з Квебеку 1792 р. Наприкінці ХIX ст. з'явилися перші журнали, які друкували оповіді в малюнках: «Le Chat Noir» (1882), «Le Petit Français illustré» (1889), тоді ж світ побачили комікси графіка Крістофа «La famille Fenouillard» (1889), «Les Facéties du sapeur Camember» (1890-1896), «L'idée fixe du savant Cosinus» (1893-1899), «Les Malices de Plick et Plock» (1893-1904), «Le Baron de Cramoisy» (1899), які були популярними до 1970 -х років.

У середині XX століття популярними журналами коміксів були Спіру (фр. Spirou, 1938) та Тентен (фр. Tintin, 1946). Тематика Спіру гумор, Тентена - пригоди. У Спіру друкувалися: А. Франкін «Spirou et Fantasio» (1938), «Modeste et Pompon» (1955), «Gaston» (1957); Ф. Дінер «Tif et Tondu» (1938); Ж. Жіллен (псевдонім Жіже) «Aventures de Jean Valhardi» (1941), «Jerry Spring» (1954); Е. Паапе «Les aventures de Jean Valhardi» (1941), «Marc Dacier» (1960); Cipiyc «L'Epervier bleu» (1942), «Les Timour» (1953); Moppic «Lucky Luke» (1946); Пейо «Johan et Pirlouit» (1952), «Les
Schtroumpfs» (1958), «Benoît Brisefer» (1960); М. Тілье «Gil Jourdan» (1956), «Marc Lebut et son voisin» (1966); Ж. Роба «Boule et Bill» (1959), «La Ribambelle» (1962); Ж. де Месмекер (псевдонім Іідем) «Sophie» (1965); Р. Макерот «Sibylline» (1967), «Isabelle» (1972).

У журналі Тентен друкувалися такі автори: Ж. Ремі (псевдонім Ерже) «Les Aventures de Tintin» (1946); Е. Якобс «Blake et Mortimer» (1946); Ж. Мартен «Alix» (1948); П. Кювье «Corentin» (1950), «Flamme d'Argent» (1960-1963), «Wapi» (1962-1966); Ж. Гратон «Michel Vaillant» (1957).

Культовими авторами BD цього періоду $\epsilon$ Ж. Жиро (псевдонім Мебіус), А. Ходоровський, Ж. Ремі, А. Удерзо. Двоє останніх увійшли в історію завдяки гумористичним і дитячим творам. Інші - відомі своїм авангардним та фантасмагоричним доробком із присмаком безуму, де багато авантюр, пригод та похмурих картин майбутнього.

Ерже всесвітньо відомий завдяки серії коміксів «Пригоди Тентена» (фр. Aventures de Tintin). Йому належать такі персонажі, як Тентен (3'явився 1929 р., головний герой - молодий журналіст, який боровся зі злочинцями, диктаторами, прославляв дружбу і захищав місцеве населення). Крім книг про Тентена, письменник створив і ряд творів про інших персонажів. До них відносяться Квік та Флюпке, Пополь та Віржин. Усупереч тематиці творів, яка охоплює політичні, літературні й кінематографічні алюзії, соціальні проблеми, Ерже був дуже стриманий щодо іронії, жорстокості, його герої мають позитивний характер, i на передньому плані знаходяться захоплюючі пригоди i несподівані повороти сюжету.

Астерікс ((фр. Astérix) - галльський герой, що веде відважну боротьбу з римськими загарбниками, став головним персонажем гумористичної серії французьких коміксів «Пригоди Астерікса» А. Удерзо та Р. Госіні. Серія розпочалася у 1959 р. в журналі «Pilote» (1959-1989). Станом на 2019 р. видано 37 томів коміксів. Серія про Астерікса - один із найпопулярніших коміксів у Франції, Бельгії, інших франкомовних країнах i не тільки, комікс є одним із найкращих гумористичних циклів усіх часів. Комікс і дотепер серйозно досліджують науковці та любителі: Ф. Лакасен, А. Ресне, П. Френо-Дерюель тощо. Серія перекладена більше ніж ста мовами світу, кілька томів екранізовано - випущено 10 мультфільмів та чотири фільми. На основі коміксів створені численні ігри. Неподалік Парижа існує також тематичний «Парк Астерікса». На перший погляд, «Астерікс» належить до дитячих та сімейних коміксів, однак там присутні сатира, іронія 
над політиками та бюрократами, подеколи дорослий гумор, що робить цей комікс універсальним.

У провідному французькому тижневику 60-х років «Pilote» друкувалися й Ж.-М. Шарльє та А. Удерзо «Tanguy et Laverdure» (1959); Ж.-М. Шарльє та В. Хубінон «Barbe-Rouge» (1959); Ж.-М. Шарльє «Blueberry» (1963) тощо.

До 1970-х років комікси друкувалися здебільшого в дитячих журналах «Guignol» (1919-1936), «Lisette» (1921-1973), «Pierrot» (1925-1957), внаслідок чого його ототожнювали 3 дитячою розважальною літературою. Комікс став окремим жанром аж наприкінці $1970-\mathrm{x}$ років. У той час він почав орієнтуватись і на підлітків. Популярними авторами кінця XX ст. є: К. Сер «Humour noir et Hommes en blanc» (1972); Ф. Буржон «Les Passagers du vent» (1979-2018), «Les Compagnons du crépuscule» (1984-1992), «Le Cycle de Cyann» (1993-2016); А. Жюйяр «Les 7 Vies de l'Epervier» (1983-1991), «Masque rouge» (1984), «Plume aux vents» (1995-2000); Ф. Дермо «Les Chemins de Malefosse» (1983-2016), «Malefosse» (2007-2009); Ф. Берковісі «Les femmes en blanc» (1986-2019); П. Траншан (псевдонім Піка) «Les Profs» (2000), «Marine» (1984-1992), «L'Ecole Abracadabra» (1991-2000).

Наприкінці 70-х рр. комікс почав перетворюватись у графічний роман. У Франції першими авторами графічних романів були Д. Комес «L'Ombre du Corbeau» (1976), «La Belette» (1983); Ж.-К. Форест, Ж. Тарді «Ici-même» (1979); Ф. Шутен, Б. Пітерс «Les Cités obscures» (1983),що друкувалися в журналі «А̀ suivre». Тут друкувалися й зарубіжні коміксмейкери, що посприяло поширенню французького коміксу за кордоном.

У журналах «V Magazine» (1962), «l’Écho des savanes» (1972) публікувалися «дорослі» комікси, наприклад, «Barbarella» (Ж.-К. Форест, 1964), «Blanche Épiphanie» (Ж. Пiшар, 1967), «Le Cordon infernal» (К. Бретечер, 1976). Відомими є також журнали «Hara-Kiri» (1960), «Charlie» (1969), «Charlie Hebdo» (1970), «Fluide Glacial» (1974) тощо. Автори цього періоду широко використовують політичну і соціальну сатиру. Тут почали творчу діяльність такі автори, як Ж. Воленскі «Histoires lamentables» (1965), «Ils ne pensent qu'à ça» (1967), «Vive la France!» (2013); Ж.-М. Рай3ep «Ils sont moches» (1970), «Mon Papa» (1971); Ж. Блондо (фр. Gébé) «L'An 01» (1972), «Une plume pour Clovis» (1975), «Armée Non!» (1981).

Газета «France-Soir» (1944) пропонувала комікси для всієї родини.

Одним із кращих комікс-журналів Свропи став французький журнал «Metal Hurlant» (1975-1987).
Тут публікувалися Е. Білал, Ж.-П. Діоннет, Ф. Друлле, Мебіус, Ж. Тарді, Б. Фаркас тощо.

3 метою створити незалежне видавництво, в якому автори самі могли вирішувати про зміст своєї роботи, коміксмейкери Ж.-К. Меню, Л. Трондейм, Б. Давід, М. Контюр, П. Кіллоффер, С. Бартелемі та Мокеї 1990 р. заснували французьке видавництво Асосьясьйон (фр. L'Association). Видавництво розвиває найсучасніші тенденції франко-бельгійського коміксу. Визнання та комерційний успіх видавництву принесли автори Ж. Сфар «Professeur Belle» (1999-2006), «Petit Vampire» (1999-2019), «Le Chat du rabbin» (2002-2019) та M. Сатрапі «Persepolis» (2000-2003), «Broderies» (2003), «Poulet aux prunes» (2004). Іншими відомими авторами французьких коміксів XXI століття $є$ Ф. Буале, К. Блен, Е. Жібер, Е. Браво, Б. Віве, Ф. Рюппер, Ж. Мюло, К. Меріс, К. Вар тощо.

Поза увагою французів не залишилася й політична ситуація в Україні. Француз О. Дюкудре (сценарій) і малайзієць К. Алієл (малюнки) випустили комікс «Maidan love» (2019) про події Революції гідності, що відбувалися в Києві у лютому 2014 року. Головними негативними героями в коміксах французькі автори показали «націоналістів і майже фашистів» від партії «Свобода».

У сучасній літературі розрізняють низку видів коміксів. Розглянемо основні:

1) Сингл (англ. Single) - це одиничний випуск серійного коміксу;

2) ТРВ (англ. Trade Paper Back) - це довгі історії (від 90 сторінок) або зібрані в одній книзі кілька синглів, тобто кілька частин;

3) Гардковер (англ. Hardcover) - збірка певної кількості номерів якоїсь серії, або випусків серії за певний період;

4) Омнібус (англ. Omnibus) - більше 1000-сторінкові збірки повних серій або лише більше половини номерів різних повних серій;

5) Графічний роман (англ. Graphic novel) завершена історія, за обсягом більша від синглу і за кількістю персонажів та сюжетною структурою аналогічна до прозового роману. Сюжет подається через серію послідовних малюнків, які супроводжуються коротким текстом та репліками дійових осіб (wikipedia).

Комікс є невід'ємною складовою частиною Інтернет-середовища. Новими явищами в цьому виді мистецтва $\epsilon$ блоги-комікси, наприклад, таємничий Frantico та веб-комікси. У комікcax не обов'язково присутній текст, існують i німі комікси з інтуїтивно зрозумілим сюжетом (напр. «Арзак» Ж. Жиро). 
Основними елементами верстки коміксу є: панель, фрейм або бокс; поділ; сплеш, сплешсторінка; хмарка, балун, текстова хмаринка, бабл; вигуки, звуки або ономатопея.

Як бачимо, комікс пройшов довгий та цікавий шлях, і з часом карикатури 3 цікавими та простими історіями розвинулися в літературне середовище з багатьма піджанрами: комедії, екшену, пригод (бойовики, детективи, жахи, фантастика, вестерн, мелодрама, політика, історії про супергероїв), сатири, антиутопії, автобіографії. Розрізняють й історичні, езотеричні, рекламні та агітаційні комікси тощо, і кожен із цих жанрів має своїх постійних прихильників. Насамперед комікси орієнтовані на масового читача та дітей. Для них характерні корпоративні персонажі (напр. супергерої). Найпоширенішими жанрами коміксу й досі $є$ пригоди та гумор.

Франко-бельгійські комікси тяжіють до реалізму, авангарду, гумористики, орієнтуються на вимогливого та інтелектуально підкутого читача. Окрім розважальної функції, комікси виконують і освітню роль, привчаючи дітей до читання й формуючи інтерес до пізнання історії. Тематика коміксів дуже різноманітна - від героїзму, шпіонажу, битви до реалістичної і дорослої: корупція, вбивства, викрадення, вживання наркотиків, алкоголізм, забруднення навколишнього середовища, расизм тощо. Незважаючи на всю різноманітність стилів і жанрів, основним завданням коміксу $\epsilon$ викликати в читача почуття й емоції.
Для французів комікс - це інструмент для розвитку візуальної та загальної культури. За статистичними даними, за рік французи читають по 6 альбомів Bande Dessinée. Крім того, франко-бельгійський комікс є лідером на європейській арені. Комікси власного виробництва вони вважають дев'ятим видом мистецтва і ледь не національним надбанням. У Бельгії існує Бельгійський центр коміксів - музей, присвячений бельгійським коміксам. Там організовуються виставки, присвячені історії коміксів, мистецтву малювання коміксів, героям коміксів. Музей налічує понад 3000 коміксів на 36-ти мовах.

Коміксу також присвячений щорічний Міжнародний фестиваль коміксів у Ангулемі - найбільший європейський фестиваль коміксів. Серед премій авторам коміксів можна назвати: Prix du meilleur album, Les Essentiels d'Angoulême, Grand Prix de la ville d'Angoulême та інші.

Отже, можна зробити висновок, що комікс $\epsilon$ важливим феноменом сучасної культури, а не дитячою забавкою, він здобув статус 9-го виду мистецтва. У багатьох країнах організовуються виставки, фестивалі саме цього виду мистецтва. Комікс має свою суперсилу, адже впливає на формування громадянської та суспільної активності нинішнього покоління. Кожен читач знайде улюблену історію, адже його аудиторія різновікова та різноцільова.

Перспективою подальших наукових пошуків $\epsilon$ дослідження вербальних та невербальних компонентів франко-бельгійського коміксу.

\section{СПИСОК ВИКОРИСТАНИХ ДЖЕРЕЛ}

1. Барзах А. В. Поэтика комикса. Русский комикс : сб. статей. Москва, 2010. С. 9-55.

2. Данкан Р., Сміт М., Левіц П. Сила коміксів. Історія, форма й культура / пер.з англ. Д. Скорбатюка. Київ : ArtHuss, 2020. 512 c.

3. Івасишин М. Р. Мультимодальність англомовного коміксу : лінгвальний і екстралінгвальний виміри : автореф. дис. ... канд. філол. наук : 10.02.04. Львів, 2019. 22 с.

4. Калініна-Шамрай В. Р., Соболєва О. В. Символічна активність та семантика французького коміксу. Вісник Київського національного університету імені Тараса Шевченка. Іноземна філологія. Київ, 2013. Вип. 1 (46). С. 41-44.

5. Козлов Е. В. Комикс как явление лингвокультуры : знак - текст - миф. Волгоград : Изд-во ВолГУ, 2002.183 с.

6. Комікс. URL :https://uk.wikipedia.org/wiki/\%D0\%9A\%D0\%BE\%D0\%BC\%D1\%96\%D0\%BA\%D1\%81 (дата звернення: 30.09.2020).

7. Космацька Н. В. Нарис з історії виникнення і становлення жанру коміксу. Вісник Львівського університету. Іноземні мови. Львів, 2012. Вип. 19. С. 141-147.

8. Словник української мови : в 11 т. / заг. ред. І. К. Білодід, А. А. Бурячок. Київ : Наук. Думка, 1973. Т. 4. 840 с.

9. Сонин А. Г. Комикс : психолингвистический анализ. Барнаул : Издательство Алтайского госуниверситета, 1999. $111 \mathrm{c}$.

10. Харитонов Е. В. Девятое искусство : зарубежный фантастический комикс : (Историко-критический очерк и путеводитель). Москва : Academia-F, 2005. 95 с.

11. Baron-Carvais A. La bande dessinée. Paris, 1985. 219 p.

12. Fresnault-Deruelle P. Récit par la bande. Paris : Hachette, 1977. 253 p.

13. Lacassin F. Pour un neuvième art : la B.D. Paris : Editions Slatkine, 1982. 508 p.

14. Masson P. Lire la bande dessinée. Lyon : Presse Universitaire de Lyon, 1985. $154 \mathrm{p}$.

15. McCloud S. Understanding Comics. Tundra Publishing, 1993. 215 p. 


\section{REFERENCES}

1. Barzakh, A. V. (2010). Poetika komiksa [Poetics of comics]. Russkiy komiks. Moskva. Pp. 9-55 [in Russian].

2. Dankan, R., Smit, M., Levits, P. (2020). Syla komiksiv. Istoriya, forma y kul'tura [The Power of Comics: History, Form, and Culture]. / per. z anhl.D. Skorbatyuka. Kyiv: ArtHuss. 512 p. [in Ukrainian].

3. Ivasyshyn, M. R. (2019). Mul'tymodal'nist' anhlomovnoho komiksu: linhval'nyy i ekstralinhval'nyy vymiry [Multimodality of English comics: lingual and extralingual dimensions]. Avtoref. dys. ... kand. filol. nauk: 10.02.04. L'viv, 22 p. [in Ukainian].

4. Kalinina-Shamray, V. R., Sobolyeva, O. V. (2013). Symvolichna aktyvnist' ta semantyka frantsuz'koho komiksu. [Symbolic activity and semantics of French comics.] Visnyk Kyyivs'koho natsional'noho universytetu imeni Tarasa Shevchenka. Inozemna filolohiya. Kyiv. Vyp. 1(46). Pp. 41-44 [in Ukainian].

5. Kozlov, Ye. V. (2002). Komiks kak yavleniye lingvokul'tury: znak - tekst - mif [Comics as a Phenomenon of Linguoculture: Sign - Text - Myth.]. Volgograd: Izd-vo VolGU. 183 p. [in Russian].

6. Komiks. URL :https://uk.wikipedia.org/wiki/\%D0\%9A\%D0\%BE\%D0\%BC\%D1\%96\%D0\%BA\%D1\%81 (30.09.2020) [in Ukrainian].

7. Kosmats'ka, N. V. (2012). Narys z istoriyi vynyknennya i stanovlennya zhanru komiksu [Essay on the history of the origin and formation of the comic book genre]. Bulletin of Lviv University. Foreign languages. L'viv. Issue. 19. Pp. 141-147 [in Ukrainian].

8. Slovnyk ukrayins'koyi movy: v 11 t. (1973). [Dictionary of the Ukrainian language: in 11 volumes]. Kyiv: Nauk. Dumka. T. 4 / zah. red. I. K. Bilodid, A. A. Buryachok. 840 p. [in Ukrainian].

9. Sonin, A. G. (1999). Komiks: psikholingvisticheskiy analiz [Comics: Psycholinguistic Analysis]. Barnaul: Izdatel'stvo Altayskogo gosuniversiteta. 111 p. [in Russian].

10. Kharitonov, Ye. V. (2005). Devyatoye iskusstvo: zarubezhnyy fantasticheskiy komiks: (Istoriko-kriticheskiy ocherk i putevoditel') [Ninth Art: Foreign Fantastic Comics: (Historical and critical essay and guide)]. Moskva: Academia-F. 95 p. [in Russian].

11. Baron-Carvais, A. (1985). La bande dessinée. Paris. 219 p. [in French].

12. Fresnault-Deruelle, P. (1977). Récit par la bande. Paris: Hachette. 253 p. [in French].

13. Lacassin, F. (1982). Pour un neuvième art: la B.D. Paris: Editions Slatkine. 508 p. [in French].

14. Masson, P. (1985). Lire la bande dessinée. Lyon : Presse Universitaire de Lyon. 154 p. [in French].

15. McCloud, S. (1993). Understanding Comics. Tundra Publishing. 215 p. [in English]. 